\title{
Detection of sperm-reactive antibodies in wild sika deer and identification of the sperm antigens
}

\author{
Osamu KAWASE ${ }^{1) *}$ and Mitsuru JIMBO2) \\ 1)Department of Biology, Premedical Sciences, Dokkyo Medical University, Mibu-machi, Shimotsuga-gun, \\ Tochigi 321-0293, Japan \\ 2) Department of Marine Biosciences, School of Marine Biosciences, Kitasato University, Kitasato, Sagamihara, \\ Kanagawa 252-0373, Japan
}

J. Vet. Med. Sci.

80(5): 802-809, 2018

doi: 10.1292/jvms.17-0660

Received: 5 December 2017

Accepted: 5 March 2018

Published online in J-STAGE:

16 March 2018

\begin{abstract}
Antisperm antibodies potentially inhibit sperm functions causing the sterility in humans and experimentally treated animals. However, there is no information about antisperm antibodies emerging spontaneously in wildlife. In this study, we searched for the sperm-reactive antibodies, spontaneously produced in wild sika deer (Cervus nippon), and identified the sperm antigens. We collected 529 fecal masses of sika deer in Japanese cities, from which we extracted the mucosal antibodies to test them for reactivities to deer sperm proteins by ELISA. Two of the extracts contained IgAs that were highly reactive to the sperm proteins. The molecular weights of the active IgAs, partially purified by DEAE-sephadex A-50, were estimated at more than $100 \mathrm{kDa}$, suggesting that the IgAs evaded drastic digestion in the gastrointestinal tract. Two-dimensional electrophoresis and immunoblotting detected three major antigens, and the following LC-MS/ MS analysis identified them as alpha-enolase, phosphoglycerate kinase 2 and acrosin-binding protein. The antibodies were cross-reactive to a recombinant human acrosin-binding protein. To our knowledge, this is the first research to find that the sperm-reactive antibodies are produced spontaneously in wildlife and they recognize a common antigen found in humans.
\end{abstract}

KEY WORDS: Cervus nippon, sika deer, sperm antigen, sperm-reactive antibody

Sperm have both auto- and iso-antigenic potentials to induce antisperm antibodies in mammalian species [26]. Antisperm antibodies sterilize the animals by affecting the pre-fertilization events, such as sperm viability, motility, transport, capacitation, acrosome reaction and interaction with zona pellucida, and the post-fertilization events, such as early embryonic development, implantation and fetal development [29]. A lot of studies indicated that various animals including humans become infertile by the immunization with testicular or seminal materials [26]. Furthermore, the contraceptive effects of some antigens have been demonstrated in mice, rats, rabbits and guinea pigs [15]. In primates, the inoculation of two sperm antigens ( $\mathrm{LDH}-\mathrm{C}_{4}$ and Eppin) were shown to suppress the reproduction in baboons and macaques respectively [17, 20].

Antisperm antibodies occasionally emerge without such an active immunization. Repeat-breeding cows are frequently exposed to sperm antigens and produce sperm-reactive antibodies [23]. Some of the antibodies agglutinate and/or immobilize bull sperm, presumably reducing their fecundities. In humans, sperm-reactive antibodies are detected in 9 to $36 \%$ of infertile couples, 8 to $21 \%$ of infertile men and 6 to $23 \%$ of infertile women [14]. The production of sperm-reactive antibodies is normally suppressed, because sperm and the precursor cells are prevented from contact with the immune system by anatomical barrier and T regulatory (Treg) cells are serve for the immunological tolerance to male antigens [22, 30]. However, the testicular injuries, such as testicular torsion, surgery and trauma, can possibly cause the exposure of sperm antigens to immune cells [1,9]. The infectious agents can also invalidate the $\mathrm{T}_{\text {reg }}$-dependent tolerances [31].

The antibodies may be the key for infertility treatment and contraception. However, the knowledge in wildlife is insufficient because no attempt has been performed to find the antibodies naturally emerge in wildlife. Therefore, we searched for the spermreactive antibodies, spontaneously produced in wild sika deer (Cervus nippon), and identified the sperm antigens. 


\section{MATERIALS AND METHODS}

\section{Preparation of sperm stock}

Two male deer were hunted in a forest in Nikko, Japan by the Japanese hunting association (Ryoyukai) in conformity with the Specified Wildlife Conservation and Management Plan of Tochigi prefecture, and the testes with attached epididymides and vasa deferentia were excised by them and provided us. The testes were transported on ice to a laboratory in Dokkyo Medical University. Five $\mathrm{m} l$ phosphate buffered saline (PBS, Wako, Osaka, Japan) was infused into the lumen of vas deferens and caudal epididymis by a syringe. After the swollen cauda epididymis was washed with PBS to avoid the contamination of sperm with blood, it was then cut with a surgical knife to flush the sperm into a test tube. The sperm from two deer were mixed and washed three times with PBS by centrifugation $\left(250 \times \mathrm{g}, 5 \mathrm{~min}, 20^{\circ} \mathrm{C}\right)$, and the final precipitate was stored at $-60^{\circ} \mathrm{C}$ before use. We checked that sperm had normal shape and motility, and the contamination of sperm with blood was negligible by observing it under a microscope at 1,000 $\times$ magnification. The Institutional Animal Care and Use Committee of Dokkyo Medical University approved all procedures.

\section{Preparation of fecal extracts}

Four hundred ninety-two fecal masses were collected in Nara, Japan in February 2013 and 37 fecal masses in Kushiro, Japan in March 2013. Deer fecal mass is composed of many round feces, which do not stick together and are normally strewn on the ground after evacuation. We picked up some feces probably evacuated together and handled them as a "fecal mass". The freshness of fecal masses was estimated by their moisture and solidity. Dry crumbly fecal masses were not collected. Feces were homogenized and mixed with 3-fold volume of PBS for $15 \mathrm{~min}$ at room temperature. After centrifugation $\left(15,000 \times \mathrm{g}, 20 \mathrm{~min}, 4^{\circ} \mathrm{C}\right)$, the supernatants were collected and stored at $-60^{\circ} \mathrm{C}$ before use.

\section{Partial purification of sperm-reactive antibodies by DEAE-sephadex A-50}

Fifteen $\mathrm{m} l$ fecal extract (K24 from Kushiro or N459 from Nara) was extensively dialyzed with a dialysis device, Float-A-Lyzer G2 (3.5-5 kDa cutoff, Spectrum Laboratories, Rancho Dominguez, CA, U.S.A.) against 20-fold diluted PBS ( $\times 1 / 20$ PBS) at room temperature. Fifteen $\mathrm{m} l$ of DEAE-sephadex A-50 (GE Healthcare, Buckinghamshire, U.K.) rehydrated in $\times 1 / 20$ PBS, was added into the dialyzed extract and they were mixed overnight at room temperature. The supernatant was collected as "Flow through" fraction. The remaining resin was washed four-times with $25 \mathrm{~m} l$ of $\times 1 / 20$ PBS. The first washing solution was collected as "Wash" fraction. The substances bound to the resin were eluted twice with three solutions, i.e. 2 -fold diluted PBS $(\times 1 / 2$ PBS $)$, PBS and 5-fold concentrated PBS ( $\times 5$ PBS), successively.

\section{Separation of sperm-reactive antibodies by ultrafiltration}

Five hundred $\mu l$ of the "Flow through" fraction was concentrated up to $15 \mu l$ by a Nanosep centrifugal device with $100 \mathrm{kDa}$ cutoff (Pall Life Sciences, Ann Arbor, MI, U.S.A.) and diluted again with $485 \mu l$ PBS ("> $>100 \mathrm{kDa}$ " fraction). Twenty-four $\mu l$ of 20 -fold concentrated PBS $(\times 20$ PBS) was added to the solution that passed through the filter membrane (" $<100 \mathrm{kDa}$ " fraction). These processes adjusted the salt concentration of " $>100 \mathrm{kDa}$ " and " $<100 \mathrm{kDa}$ " fractions to that of PBS.

\section{Measurement of IgA amount by ELISA}

The fecal extracts and separated fractions were 4-fold diluted using $0.05 \mathrm{M}$ carbonate buffer (pH9.6). Fifty $\mu l$ of this solution was then added to the wells of a 96-well ELISA plate (IWAKI, Tokyo, Japan) and kept overnight at $4^{\circ} \mathrm{C}$. The wells were washed once with PBS containing $0.05 \%$ Tween 20 (PBST) and blocked by $100 \mu \mathrm{l}$ PBST containing 3\% skim milk (blocking solution) for $1 \mathrm{hr}$ at $37^{\circ} \mathrm{C}$. They were washed once with PBST and treated for $1 \mathrm{hr}$ at $37^{\circ} \mathrm{C}$ with $50 \mu \mathrm{l}$ of Horseradish peroxidase (HRP)conjugated anti-bovine IgA antibody produced in sheep (Bethyl Laboratories, Montgomery, TX, U.S.A.) which was 2,000-fold diluted with the blocking solution. After the wells were washed six times with PBST, color development reaction was induced by ELISA POD Substrate TMB Kit (Nacalai Tesque, Kyoto, Japan), and the light absorbance at $450 \mathrm{~nm}\left(\mathrm{OD}_{450}\right)$ was measured by a spectrophotometer, Infinite 200 Pro (Tecan Trading AG, Männedorf, Switzerland).

Because HRP-conjugated anti-bovine IgA antibody was similarly reactive to the extracts of bovine feces and deer feces, but not reactive to the extract of rat feces, we concluded that this antibody was available for the detection of deer fecal IgA.

\section{Evaluation of the reactivities of IgAs to sperm proteins by ELISA}

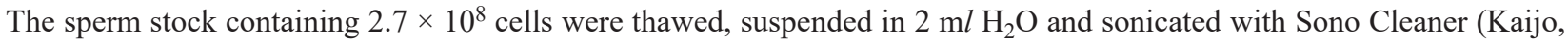
Tokyo, Japan) for $30 \mathrm{~min}$ at room temperature. The supernatant was collected by centrifugation $(15,000 \times \mathrm{g}, 20 \mathrm{~min}$, room temperature), and added to $28 \mathrm{~m} l$ of $0.05 \mathrm{M}$ carbonate buffer (pH9.6). Fifty $\mu l$ of the antigen solution was added to the wells of a 96-well ELISA plate and kept overnight at $4^{\circ} \mathrm{C}$. The wells were washed once with PBST and blocked by $100 \mu l$ of blocking solution for $1 \mathrm{hr}$ at $37^{\circ} \mathrm{C}$. They were washed once with PBST and treated with $50 \mu l$ of primary antibodies, i.e. the fecal extracts or the partially purified fractions, which were added $0.05 \%$ Tween 20 before the treatment. The wells were washed six times with PBST, and reacted for $1 \mathrm{hr}$ at $37^{\circ} \mathrm{C}$ with $50 \mu \mathrm{l}$ of HRP-conjugated anti-bovine IgA antibody, which was 2,000-fold diluted with the blocking solution. After the wells were washed again six times with PBST, the HRP color development reaction was induced by ELISA POD Substrate TMB Kit, and the $\mathrm{OD}_{450}$ was measured by Infinite 200 Pro.

The relative reactivity of each extract was calculated using the following formula:

Relative reactivity $=\left(\mathrm{OD}_{450}-\mathrm{OD}_{450 \text { ave }}\right) / \mathrm{SD}$ 
$\mathrm{OD}_{450 \text { ave }}$ was the average $\mathrm{OD}_{450}$ of all extracts tested simultaneously, and $\mathrm{SD}$ was the standard deviation.

To measure the reactivities of IgAs to human acrosin-binding protein (hACRBP, OriGene Technologies, Rockville, MD, U.S.A.), we used $5 \mu \mathrm{g} / \mathrm{m} l \mathrm{hACRBP}$ in $0.05 \mathrm{M}$ carbonate buffer (pH9.6) to immobilize the antigen on the ELISA plate.

\section{Two-dimensional electrophoresis}

Sperm $\left(1.3 \times 10^{8}\right.$ cells $)$ were suspended in $\mathrm{H}_{2} \mathrm{O}$ containing 1\% 3-(3-cholamidepropyl) dimethylammonio-1-propanesulphonate (CHAPS, Dojindo Molecular Technologies, Kumamoto, Japan) and mixed for $15 \mathrm{~min}$ at room temperature. The sperm proteins solubilized in the supernatant were collected by centrifugation $\left(15,000 \times \mathrm{g}, 10 \mathrm{~min}, 20^{\circ} \mathrm{C}\right)$ and then chilled on ice. The proteins were precipitated with $500 \mu l$ of cold $10 \%$ trichloroacetic acid (TCA) and washed three times with $500 \mu l$ of cold acetone. The precipitate was dissolved in $50 \mu \mathrm{l}$ of the sample buffer (7M urea, 2M thiourea, 4\% CHAPS, $100 \mathrm{mM}$ dithiothreitol, $60 \mathrm{mM}$ tris (hydroxymethyl) aminomethane (Tris) $\mathrm{pH} 8.8$ ) and was added to $5 \mu l$ of $100 \mathrm{mM}$ acrylamide for propionamidation of cysteine residues. An agarose gel strip, agarGEL (pH3-10, $75 \mathrm{~mm}$ ) (ATTO, Tokyo, Japan) was used to separate proteins in the first dimension. The separation was achieved with an isoelectric machine (DiscRun-R (ATTO)) using a stepwise output (50 V for 10 min, $100 \mathrm{~V}$ for $10 \mathrm{~min}, 300 \mathrm{~V}$ for $210 \mathrm{~min}$ ). The agarGEL was incubated in $2.5 \%$ TCA for 3 min and washed five times with $\mathrm{H}_{2} \mathrm{O}$. It was soaked in the equilibration buffer (2\% sodium dodecyl sulfate (SDS), $0.001 \%$ bromo phenol blue, $50 \mathrm{mM}$ Tris $\mathrm{pH} 6.8$ ) and the proteins in it were resolved in the second dimension on SDS-polyacrylamide gel electrophoresis with $12.5 \%$ acrylamide gel. To detect whole proteins separated by the two-dimensional electrophoresis, the acrylamide gel was stained with Coomassie Brilliant Blue R-250.

\section{Immunoblot}

The gel of two-dimensional electrophoresis was soaked in a transfer buffer (192 mM Glycine, $25 \mathrm{mM}$ Tris, 20\% Methanol) and the proteins were transferred onto a PVDF membrane, BioTrace PVDF (Pall life Sciences) by "rapid mode" of the western blotting transfer system, PoweredBLOT ONE (ATTO), for $20 \mathrm{~min}$. The membrane was blocked by ELISA blocking solution for 1 $\mathrm{hr}$ at room temperature, and agitated for $1 \mathrm{hr}$ in $12 \mathrm{~m} l$ of the "Flow through" fraction containing $0.6 \mathrm{~m} l$ of $\times 20 \mathrm{PBS}$ and $126 \mu l$ of $5 \%$ Tween 20. It was intensively washed in Tris buffered saline (TBS, $137 \mathrm{mM} \mathrm{NaCl}, 3 \mathrm{mM} \mathrm{KCl,} 10 \mathrm{mM}$ Tris pH6.8) with 0.05\% Tween 20 (TBST), and treated for $1 \mathrm{hr}$ with HRP-conjugated anti-IgA antibody, 1,000-fold diluted with TBST containing 3\% skim milk. The solution was completely washed out by TBST and colorimetric detection was performed by a TMB substrate for HRP, EzWestBlue (Nacalai Tesque).

\section{Identification of sperm antigens}

Each protein within a gel piece of two-dimensional electrophoresis was digested overnight at $37^{\circ} \mathrm{C}$ by $5 \mathrm{ng} / \mu \mathrm{l}$ trypsin from porcine pancreas Mass Spectrometry Grade (Wako) dissolved in $25 \mathrm{mM} \mathrm{NH} \mathrm{HCO}_{3}$. The peptide mixture was extracted from the gel piece once with $25 \mathrm{mM} \mathrm{NH}_{4} \mathrm{HCO}_{3}$ and twice with $50 \%$ acetonitrile containing $0.1 \%$ trifluoroacetic acid (TFA), and these extracts were pooled. The mixture was separated by reverse-phase HPLC using a column Cadenza CD-C18 (Imtakt, Kyoto, Japan) with acetonitrile gradient of 5 to $50 \%$, and was analyzed using LC-Q-TOF TripleTOF5600 (ABSciex, Framingham, MA, U.S.A.). After conversion of data file in mgf format, the amino acid sequences of peptides were estimated by PepNovo+ with DeNovoGUI $[7,13]$. The amino acid sequences with the score of 80 or higher were collected and were compared with sequences in a publicly available reviewed protein database of Swiss-Prot (http://www.uniprot.org/downloads) using fasts36.3.6 [12].

\section{RESULTS}

\section{Search for sperm-reactive antibodies in deer feces}

Five hundred twenty-nine fecal masses of sika deer were collected from two places in Japan (Kushiro and Nara). We extracted the mucosal antibodies from each feces and evaluated whether the sperm-reactive antibodies were present in the extracts. Here, the extracts were examined for the reactivities to whole sperm proteins by ELISA, in which a labeled anti-IgA antibody was used as the secondary antibody, because IgA was the major immunoglobulin class in the mucosal immunity. Two of 529 extracts, K24 from Kushiro and N459 from Nara, were highly reactive to sperm proteins (Fig. 1). Their relative reactivities were 7.3 (K24) and 6.7 (N459) respectively, which meant that their $\mathrm{OD}_{450}$ values were bigger than the average by 7.3 and 6.7 times of the standard deviation. In addition, the relative reactivities of 8 other samples, N16, 106, 107, 219, 224, 242, 381 and 462, were more than 3.0. We focused on K24 and N459 to characterize the naturally emerging sperm-reactive antibodies and investigate the sperm antigens.

\section{Partial purification of sperm-reactive antibodies}

Because the samples were just extracted directly from feces, they contained impurities. To improve the purity and avoid the unexpected effects of the impurities, the components of K24 and N459 were respectively separated by an anion exchange resin, DEAE Sephadex A-50. The components were separated into the fractions unbound to the resin ("Flow through" and "Wash" fractions) and the fractions bound (“× $1 / 2$ PBS", " $\times 1$ PBS" and " $\times 5$ PBS" fractions). We clearly found the IgAs were composed of the unbound and bound populations, because IgA amounts decreased once in " $\times 1 / 2$ PBS" fraction and increased again in the following fractions (Fig. 2 upper graphs). Furthermore, IgAs in the unbound fractions reacted to sperm proteins (Fig. 2 lower graphs).

It is generally known that the molecular weights of mammalian IgA are about $170 \mathrm{kDa}$ in the monomer and $390 \mathrm{kDa}$ in the dimer. Therefore, we confirmed that the active IgAs in our extracts were as large as the general mammalian IgA. The components 


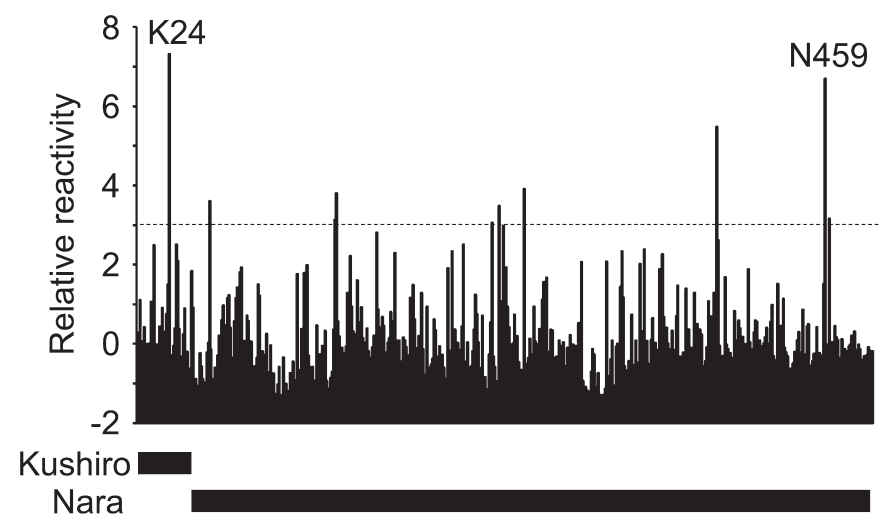

Fig. 1. Reactivities of fecal extracts to sperm antigens. Mucosal antibodies were extracted from 529 fecal masses ( 37 from Kushiro and 492 from Nara) with PBST, and the reactivities of the extracts to sperm proteins were measured by ELISA. Each value represents the average of two independent experiments. Two (K24 and N459) extracts strongly reacted to sperm proteins.
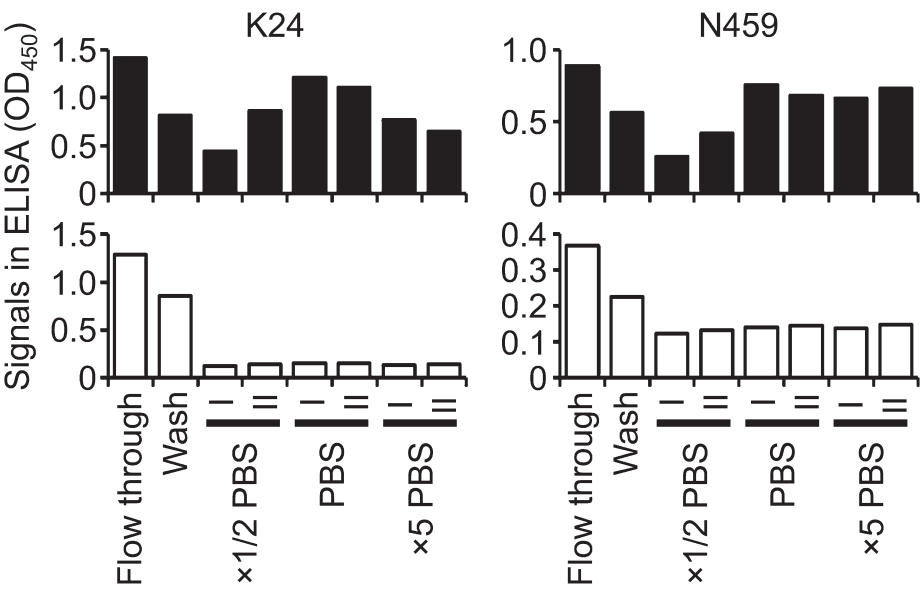

$\lg A$ amount $\quad \square$ Reactivity to sperm

Fig. 2. IgA amounts and reactivities of partially purified fractions. K24 and N459 extracts were respectively applied for DEAE Sephadex A-50. The unbound substances were collected in "Flow through" and "Wash" fractions, and the bound substances were eluted twice by $\times 1 / 2, \times 1$ and $\times 5$ PBS. The first and second fractions of each solution were indicated as "I" and "II" respectively. The relative IgA amounts (black bars) and the reactivities to sperm proteins (white bars) of each fraction were measured by ELISA. Each value represents the average of two independent experiments. IgAs were divided into both the unbound and bound fractions, but the former alone reacted to sperm proteins.

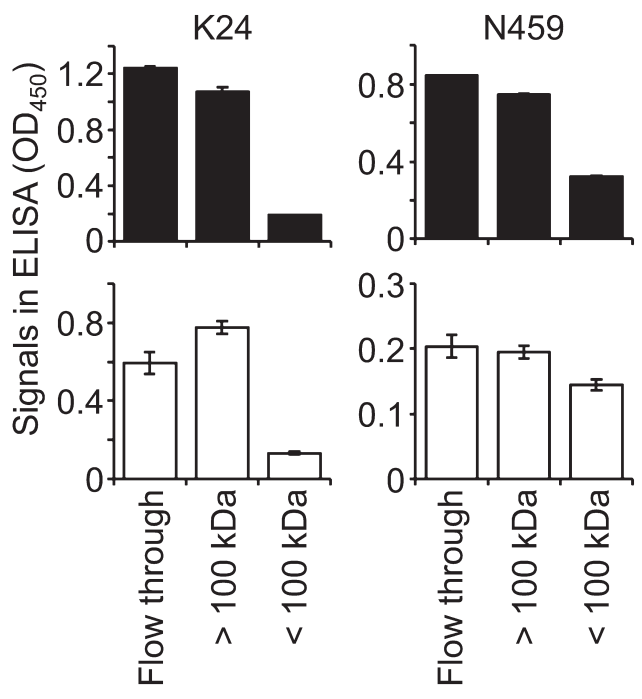

IgA amount $\square$ Reactivity to sperm

Fig. 3. IgA amounts and reactivities of ultrafiltered fractions. The "Flow through" fractions, prepared by the partial purification with DEAE Sephadex A-50 separation, were further separated by ultrafiltration devices with $100 \mathrm{kDa}$ cutoff. The substances passing through the filter membrane were pooled as " $<100 \mathrm{kDa}$ " fraction and those remaining on the filter membrane as ">100 $\mathrm{kDa}$ " fraction. The relative IgA amounts (black bars) and the reactivities to sperm proteins (white bars) were measured by ELISA. Each value represents the average \pm standard deviation of three independent experiments. Most of the IgAs were separated into the ">100 kDa" fraction and the fraction was reactive to sperm proteins.

in "Flow through" fractions of K24 and N459 were separated by ultrafiltration with $100 \mathrm{kDa}$ cutoff. Most IgAs in these fractions did not pass through the membrane of ultrafiltration devices, indicating they were bigger than $100 \mathrm{kDa}$ (Fig. 3 upper graphs). They certainly reacted to sperm proteins (Fig. 3 lower graphs). Thus, these active IgAs probably escaped from the severe destruction through the digestive tract and were kept in relatively good state even in feces.

\section{Detection and identification of sperm antigens}

The sperm proteins were separated by two-dimensional electrophoresis and the antigens were detected by the immunoblot, in 
$\mathrm{pl} 3$

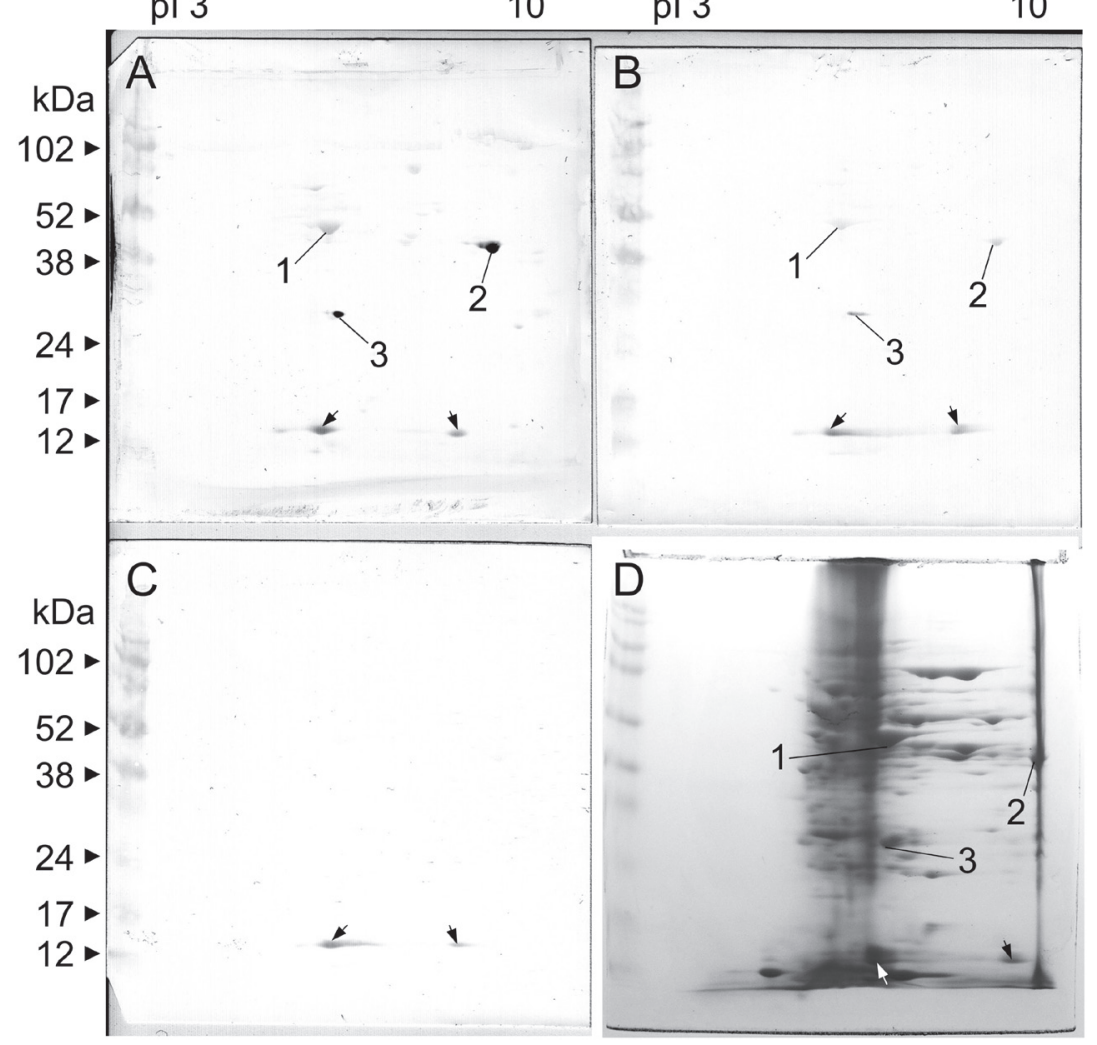

Fig. 4. Detection of the sperm antigens recognized by sperm-reactive antibodies. Sperm proteins were separated by two-dimensional electrophoresis and transferred onto PVDF membrane. On the membrane, the sperm antigens were detected by immunoblot in which the "Flow through" fractions from K24 (A) and N459 (B) were respectively used as primary antibody and HRP-conjugated, anti-IgA antibody was used as secondary antibody. In the negative control, the primary antibody was replaced by PBST (C). Simultaneously, acrylamide gel of two-dimensional electrophoresis was stained by CBB R-250 to ascertain the protein profile (D). Three antigen spots (1-3) and two non-specific spots (arrows) were detected.

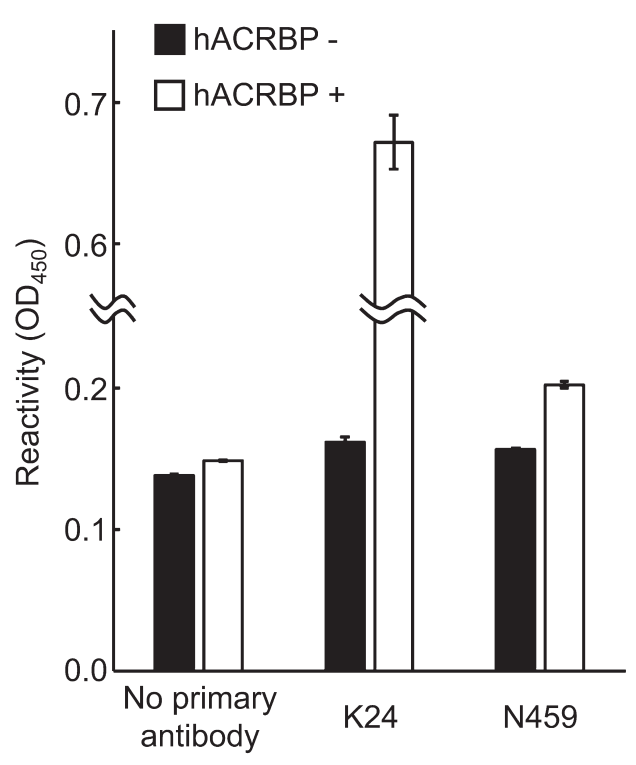

Fig. 5. Reactivities of sperm-reactive antibodies to hACRBP. The affinities of deer sperm-reactive antibodies to hACRBP were investigated by ELISA, in which hACRBP was used as antigen, the "Flow through" fractions from K24 and N459 as primary antibody, and HRP-conjugated anti-IgA antibody as secondary antibody. Each value represented the average \pm standard deviation of four independent experiments. In the negative control, the primary antibody was replaced by PBST. The deer antibodies recognized hACRBP.

which "Flow through" fractions were used for the primary antibodies, and the labeled anti-IgA antibody was used for the secondary antibody. Five major spots were detected in the immunoblot, but two of them were non-specific spots, as they were seen without the primary antibodies (Fig. 4).

The three spots, specifically recognized by "Flow through" fractions of K24 and N459, were excised from the acrylamide gel of two-dimensional electrophoresis and digested by trypsin to determine the sequences by LC-MS/MS and following de novo sequence. The determined sequences were searched against Swiss-Prot database to identify each protein. All three proteins were identified as alpha-enolase (ENO1, accession: Q9XSJ4), phosphoglycerate kinase 2 (PGK2, 2Q6RI85) and acrosin-binding protein (ACRBP, Q29016) (Table 1).

\section{Investigation of cross-reactivities of sperm-reactive antibodies to human antigen}

In the case of ACRBP identification, the number of matched peptides was relatively small and some other proteins were hit with lower scores (Table 1). Therefore, we examined the reactivities of the antibodies to a commercial recombinant hACRBP. The "Flow through" fractions of K24 and N459 certainly responded to hACRBP and especially that of K24 strongly reacted to it (Fig. 5). This result indicated both the accuracy of protein identification and cross-reactivities of the antibodies to the human sperm antigen.

\section{DISCUSSION}

\section{Incidence of the sperm-reactive antibodies}

Knowledge about antisperm antibodies has been accumulated by research conducted on humans, domestic animals and experimental animals. The physiology of humans and these animals should be affected by the artificial environment, in which they were born and grown. Their genealogy also influences their physical features. Especially, traits of domestic and experimental 
Table 1. Proteins specifically reacted to the sperm-reactive antibodies

\begin{tabular}{|c|c|c|c|c|c|}
\hline Spot no. & Matched peptide ${ }^{\text {a) }}$ & $\begin{array}{c}\text { Protein name } \\
\text { (Accession) }\end{array}$ & Species & Bit-score/E-value & $\begin{array}{c}\text { Protein function } \\
\text { (Subcellular location) }\end{array}$ \\
\hline 1 & 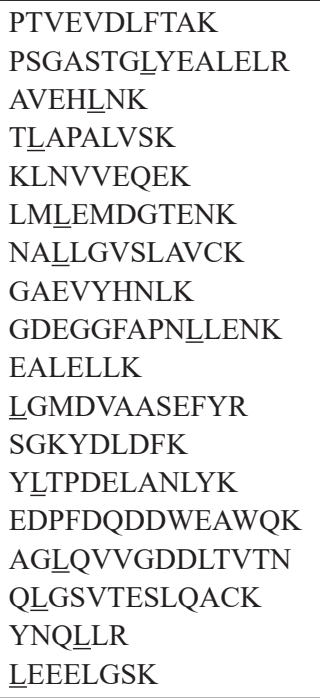 & $\begin{array}{l}\text { Alpha-enolase } \\
\text { (Q9XSJ4) }\end{array}$ & $\begin{array}{l}\text { Bos taurus } \\
\text { (Cattle) }\end{array}$ & $596.4 / 0$ & $\begin{array}{c}\text { Glycolysis } \\
\text { (Cytoplasm) } \\
\text { Plasminogen activation } \\
\text { (Cell membrane) }\end{array}$ \\
\hline 2 & 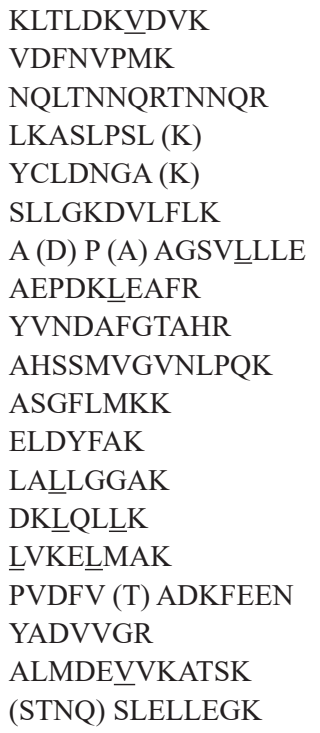 & $\begin{array}{c}\text { Phosphoglycerate } \\
\text { kinase 2 } \\
\text { (Q6RI85) }\end{array}$ & $\begin{array}{l}\text { Sus scrofa } \\
\quad \text { (Pig) }\end{array}$ & $432.5 / 0$ & $\begin{array}{l}\text { Glycolysis } \\
\text { (Cytoplasm) }\end{array}$ \\
\hline 3 & $\begin{array}{l}\text { FYGLDLYGGLR } \\
\text { QTEFLSFQDGDF } \\
\text { SQQCMMR } \\
\text { SQEFSTLTL }\end{array}$ & $\begin{array}{l}\text { Acrosin-binding } \\
\text { protein } \\
\text { (Q29016) }\end{array}$ & $\begin{array}{l}\text { Sus scrofa } \\
\quad \text { (Pig) }\end{array}$ & $129.1 / 4.4 \mathrm{E}-29$ & $\begin{array}{l}\text { Packaging and condensation of } \\
\text { acrosin zymogen } \\
\text { (Acrosome, secreted) }\end{array}$ \\
\hline
\end{tabular}

a) The amino acids underlined were replaced by the structurally similar amino acids in the homologous protein in Swiss-Prot database. The amino acids in parentheses were unmatched.

animals have been manufactured by selective breeding and/or gene manipulation. Therefore, it is possible that the previous results may have contained artifacts and/or may have concealed what happens in nature. From this point of view, we tried to detect the sperm-reactive antibodies, which were spontaneously produced in wildlife.

In our research, 2 of 529 samples were highly reactive to sperm proteins and 8 more samples were judged positive if the cutoff value of relative reactivity was 3.0 (Fig. 1). The incidence calculated with these positive samples was $1.9 \%$. A previous research showed that antisperm antibodies were detected in $14 \%$ of infertile and $2.5 \%$ of fertile men [9]. In other research, $18.8 \%$ of men and $17.6 \%$ of women in infertile couples were positive, while $4 \%$ of fertile women were positive [19]. Research in cattle, which is a relatively close species to deer, demonstrated that the incidences were much higher. Five point eight eight $\%$ of heifers, $25.00 \%$ of normal breeders, $18.75 \%$ of pregnant cows and $59.00 \%$ of repeat-breeders were positive in the sperm agglutination test [23]. Although we did not distinguish the gender and reproductive potential of individual deer, the prevalence was lower than that of fertile humans and domestic animals.

Our results are still too rough to be precisely compared with previous research because we detected the antibodies extracted from feces. Use of blood or mucous of wild deer will give us indubitable results, but it is too difficult to collect many samples. 
In fecal samples, there are some factors which may affect the incidence of sperm-reactive antibodies. The freshness of the feces may affect because the feces contain digestive enzymes, microbes, and other materials, destroying the antibodies. The partial purification of extracts showed that they contained non-reactive IgA populations (Fig. 2). N459 extract gradually lost its reactivity through the experiments. Also, we did not pick up N381, the reactivity of which was the third highest, due to rapid deterioration of its reactivity. These facts may have been due to the digestion and/or denaturation of antibodies. Meanwhile, we collected fecal masses without individual identification and some of them may have been from same deer. It is another factor possibly affecting the incidence of sperm-reactive antibodies in our research. More effort for a direct investigation with blood or mucous is required to strictly compare the incidences of the antibodies.

\section{Similarity of sperm antigens in human and wild deer}

Three sperm antigens, ENO1, PGK2 and ACRBP, were identified by two-dimensional electrophoresis and following immunoblot. They were similarly reactive to the fecal extracts from two distant places, Kushiro and Nara. It means that the antigens are common in this deer species. Furthermore, similar attempts already showed their antigenicities in human sperm. In a research, ENO1 was recognized by immunoinfertile sera, which were derived from infertile women and were positive in the sperm agglutination test, the sperm immobilization test and/or the indirect immunobead test [4]. Another research showed that ENO1 reacted with sera and seminal plasma of immunoinfertile men [6]. Simultaneously, PGK2 and ACRBP were found to react to seminal plasma of immunoinfertile men and sera of vasectomized patients respectively. The other research also indicated that ENO1 reacted to both antisperm antibody-positive and -negative sera, whereas ACRBP did only to the positive serum, but not to the negative [16].

Consequently, we detected and identified well known sperm antigens. This resemblance was supported by the cross-reactivity of ACRBP (Fig. 5). An epitope of hACRBP was already determined as KTPFVSPLL, which was recognized by CD8 T-cells [18]. This amino acid sequence is completely conserved in the ACRBP of Hungarian red deer, Cervus elaphus hippelaphus, although the homology of whole sequence is about $80 \%$ between human and the deer. These facts clearly show that both human and deer potentially develop the immune response to common sperm antigens, maybe recognizing same epitope. This is the point of our research, which suggests that sperm-reactive antibodies are not "unnatural" products limited to humans and the animals under human influences, but "natural" products similarly found in wildlife.

We guess that the common antigens might be the key molecules for "the trade-off between immunity and fertility". According to a research in a wild population of Soay sheep, individuals with strong immunity were able to survive the harsh winters, but they reproduced less during moderate winters [8].

\section{Putative action of the sperm-reactive antibodies on fertility}

The sperm antigens must be exposed on sperm surface to make the antibodies exhibit inhibitory effects. Although all antigens identified in this research are generally thought to be inside the sperm, there are some reports about their localization on sperm surface and their functions there.

ENO1 and PGK2 are generally categorized into glycolytic enzymes localized in cytoplasm. However, the proteomic analyses of surface proteins in boar and bull sperm showed that both ENO1 and PGK2 localized on sperm surface [3, 5]. As ENO1 expressing on the surface of leukocytes promotes the plasminogen activation, it is possible that it works on the sperm surface [11]. Supporting this idea, ENO1 in human sperm was shown to have affinity to recombinant zona pellucida glycoproteins [21]. Surface PGK2 also seems to be important for sperm motility in humans, as incubating sperm with anti-PGK2 antibody decreases the sperm motility $[10]$.

ACRBP is regarded as an acrosomal protein probably involved in sperm capacitation, assembling acrosin zymogen into acrosomal matrix [2]. In mice, knockout of the proprotein convertase 4 caused the loss of maturation of ACRBP and simultaneously causing head/acrosome malformations [25]. The function in acrosome formation and capacitation must be exhibited in acrosome, but instead it sorted on the surface proteins in proteomic research in mice and bull sperm [5, 24]. Additionally, another research showed an affinity of ACRBP to zona pellucida in boar sperm [27]. Moreover, boar ACRBP was found in lipid raft, which is defined as sphingolipid and cholesterol-rich micro domains in the plasma membrane concentrating signaling molecules [28].

Thus, these proteins have the potential to work on sperm surface. Deer sperm-reactive antibodies may inhibit sperm functions, especially the sperm-zona pellucida interaction and sperm motility. Unfortunately, it is unclear that the sperm-reactive antibodies really affected deer fertility, because we just collected most feces on the ground without watching their evacuations and did not checked the reproductive status of the deer from which the positive feces were derived.

To know the effect of the antibodies on deer fertility, we need further experiments to get the direct evidence. However, if the antibodies are proved to reduce deer fertility, the antigens could be utilized as the component of contraceptive vaccine. Overabundant deer population is serious issue in Japan. Hence, this research might contribute to solve the social problem.

\section{Conclusion}

We extracted the mucosal antibodies from the feces of sika deer and showed that the antibodies could react to sperm antigens, ENO1, PGK2 and ACRBP. In addition, it was demonstrated that the antibodies cross-reacted to a human antigen, hACRBP. This research firstly illustrates the spontaneous emergence of sperm-reactive antibody in wildlife and the commonness of the sperm antigens between wildlife and humans. 
ACKNOWLEDGMENTS. We are grateful to the members of the Ryoyukai for providing us with testes of wild sika deer, and to the staff of Hokusen Kaihatsu Inc., Kohfukuji Temple, Todaiji Temple, Shosoin Repository, Nara National Museum and Nara Park for helping us to collect deer feces. We also thank Mr. William G. Hassett of Department of Languages and Dr. Hamid Abid of the Office of International Affairs, Dokkyo Medical University, for the editing. This work was partially supported by the Seki Minato Prize.

\section{REFERENCES}

1. Alexander, N. J. and Anderson, D. J. 1979. Vasectomy: consequences of autoimmunity to sperm antigens. Fertil. Steril. 32: 253-260. [Medline] [CrossRef]

2. Baba, T., Niida, Y., Michikawa, Y., Kashiwabara, S., Kodaira, K., Takenaka, M., Kohno, N., Gerton, G. L. and Arai, Y. 1994. An acrosomal protein, sp32, in mammalian sperm is a binding protein specific for two proacrosins and an acrosin intermediate. J. Biol. Chem. 269: 10133-10140. [Medline]

3. Belleannee, C., Belghazi, M., Labas, V., Teixeira-Gomes, A. P., Gatti, J. L., Dacheux, J. L. and Dacheux, F. 2011. Purification and identification of sperm surface proteins and changes during epididymal maturation. Proteomics 11: 1952-1964. [Medline] [CrossRef]

4. Bhande, S. and Naz, R. K. 2007. Molecular identities of human sperm proteins reactive with antibodies in sera of immunoinfertile women. Mol. Reprod. Dev. 74: 332-340. [Medline] [CrossRef]

5. Byrne, K., Leahy, T., McCulloch, R., Colgrave, M. L. and Holland, M. K. 2012. Comprehensive mapping of the bull sperm surface proteome. Proteomics 12: 3559-3579. [Medline] [CrossRef]

6. Domagała, A., Pulido, S., Kurpisz, M. and Herr, J. C. 2007. Application of proteomic methods for identification of sperm immunogenic antigens. Mol. Hum. Reprod. 13: 437-444. [Medline] [CrossRef]

7. Frank, A. and Pevzner, P. 2005. PepNovo: de novo peptide sequencing via probabilistic network modeling. Anal. Chem. 77: 964-973. [Medline] [CrossRef]

8. Graham, A. L., Hayward, A. D., Watt, K. A., Pilkington, J. G., Pemberton, J. M. and Nussey, D. H. 2010. Fitness correlates of heritable variation in antibody responsiveness in a wild mammal. Science 330: 662-665. [Medline] [CrossRef]

9. Heidenreich, A., Bonfig, R., Wilbert, D. M., Strohmaier, W. L. and Engelmann, U. H. 1994. Risk factors for antisperm antibodies in infertile men. Am. J. Reprod. Immunol. 31: 69-76. [Medline] [CrossRef]

10. Liu, X. X., Zhang, H., Shen, X. F., Liu, F. J., Liu, J. and Wang, W. J. 2016. Characteristics of testis-specific phosphoglycerate kinase 2 and its association with human sperm quality. Hum. Reprod. 31: 273-279. [Medline]

11. López-Alemany, R., Longstaff, C., Hawley, S., Mirshahi, M., Fábregas, P., Jardí, M., Merton, E., Miles, L. A. and Félez, J. 2003. Inhibition of cell surface mediated plasminogen activation by a monoclonal antibody against alpha-Enolase. Am. J. Hematol. 72: 234-242. [Medline] [CrossRef]

12. Mackey, A. J., Haystead, T. A. and Pearson, W. R. 2002. Getting more from less: algorithms for rapid protein identification with multiple short peptide sequences. Mol. Cell. Proteomics 1: 139-147. [Medline] [CrossRef]

13. Muth, T., Weilnböck, L., Rapp, E., Huber, C. G., Martens, L., Vaudel, M. and Barsnes, H. 2014. DeNovoGUI: an open source graphical user interface for de novo sequencing of tandem mass spectra. J. Proteome Res. 13: 1143-1146. [Medline] [CrossRef]

14. Naz, R. K. 2004. Modalities for treatment of antisperm antibody mediated infertility: novel perspectives. Am. J. Reprod. Immunol. 51: 390-397. [Medline] [CrossRef]

15. Naz, R. K. 2011. Antisperm contraceptive vaccines: where we are and where we are going? Am. J. Reprod. Immunol. 66: 5-12. [Medline] [CrossRef]

16. Nowicka-Bauer, K., Kamieniczna, M., Cibulka, J., Ulcova-Gallova, Z. and Kurpisz, M. 2016. Proteomic identification of sperm antigens using serum samples from individuals with and without antisperm antibodies. Andrologia 48: 693-701. [Medline] [CrossRef]

17. O’Hern, P. A., Liang, Z. G., Bambra, C. S. and Goldberg, E. 1997. Colinear synthesis of an antigen-specific B-cell epitope with a 'promiscuous' tetanus toxin T-cell epitope: a synthetic peptide immunocontraceptive. Vaccine 15: 1761-1766. [Medline] [CrossRef]

18. Okumura, H., Noguchi, Y., Uenaka, A., Aji, T., Ono, T., Nakagawa, K., Aoe, M., Shimizu, N. and Nakayama, E. 2005. Identification of an HLA-A24restricted OY-TES-1 epitope recognized by cytotoxic T-cells. Microbiol. Immunol. 49: 1009-1016. [Medline] [CrossRef]

19. Omu, A. E., Makhseed, M., Mohammed, A. T. and Munim, R. A. 1997. Characteristics of men and women with circulating antisperm antibodies in a combined infertility clinic in Kuwait. Arch. Androl. 39: 55-64. [Medline] [CrossRef]

20. O'rand, M. G., Widgren, E. E., Sivashanmugam, P., Richardson, R. T., Hall, S. H., French, F. S., VandeVoort, C. A., Ramachandra, S. G., Ramesh, V. and Jagannadha Rao, A. 2004. Reversible immunocontraception in male monkeys immunized with eppin. Science 306: 1189-1190. [Medline] [CrossRef]

21. Petit, F. M., Serres, C., Bourgeon, F., Pineau, C. and Auer, J. 2013. Identification of sperm head proteins involved in zona pellucida binding. Hum. Reprod. 28: 852-865. [Medline] [CrossRef]

22. Robertson, S. A., Prins, J. R., Sharkey, D. J. and Moldenhauer, L. M. 2013. Seminal fluid and the generation of regulatory T cells for embryo implantation. Am. J. Reprod. Immunol. 69: 315-330. [Medline] [CrossRef]

23. Srivastava, S. K., Shinde, S., Singh, S. K., Mehrotra, S., Verma, M. R., Singh, A. K., Nandi, S., Srivastava, N., Singh, S. K., Goswami, T. K., Bhure, S. K., Kumar, H. and Ghosh, S. K. 2017. Antisperm antibodies in repeat-breeding cows: Frequency, detection and validation of threshold levels employing sperm immobilization, sperm agglutination and immunoperoxidase assay. Reprod. Domest. Anim. 52: 195-202. [Medline] [CrossRef]

24. Stein, K. K., Go, J. C., Lane, W. S., Primakoff, P. and Myles, D. G. 2006. Proteomic analysis of sperm regions that mediate sperm-egg interactions. Proteomics 6: 3533-3543. [Medline] [CrossRef]

25. Tardif, S., Guyonnet, B., Cormier, N. and Cornwall, G. A. 2012. Alteration in the processing of the ACRBP/sp32 protein and sperm head/acrosome malformations in proprotein convertase 4 (PCSK4) null mice. Mol. Hum. Reprod. 18: 298-307. [Medline] [CrossRef]

26. Tyler, A. 1961. Approaches to the control of fertility based on immunological phenomena. J. Reprod. Fertil. 2: 473-506. [CrossRef]

27. van Gestel, R. A., Brewis, I. A., Ashton, P. R., Brouwers, J. F. and Gadella, B. M. 2007. Multiple proteins present in purified porcine sperm apical plasma membranes interact with the zona pellucida of the oocyte. Mol. Hum. Reprod. 13: 445-454. [Medline] [CrossRef]

28. van Gestel, R. A., Brewis, I. A., Ashton, P. R., Helms, J. B., Brouwers, J. F. and Gadella, B. M. 2005. Capacitation-dependent concentration of lipid rafts in the apical ridge head area of porcine sperm cells. Mol. Hum. Reprod. 11: 583-590. [Medline] [CrossRef]

29. Vazquez-Levin, M. H., Marín-Briggiler, C. I. and Veaute, C. 2014. Antisperm antibodies: invaluable tools toward the identification of sperm proteins involved in fertilization. Am. J. Reprod. Immunol. 72: 206-218. [Medline] [CrossRef]

30. Wheeler, K., Tardif, S., Rival, C., Luu, B., Bui, E., Del Rio, R., Teuscher, C., Sparwasser, T., Hardy, D. and Tung, K. S. 2011. Regulatory T cells control tolerogenic versus autoimmune response to sperm in vasectomy. Proc. Natl. Acad. Sci. U.S.A. 108: 7511-7516. [Medline] [CrossRef]

31. Witkin, S. S. and Chaudhry, A. 1989. Circulating interferon-gamma in women sensitized to sperm: new mechanisms of infertility. Fertil. Steril. 52: 867-869. [Medline] [CrossRef] 